\title{
Nuclear Power and Radioactive Contamination
}

\author{
Nils-Axel Mörner \\ Paleogeophysics \& Geodynamics, Stockholm, Sweden. \\ Email: morner@pog.nu \\ Received January $4^{\text {th }}, 2014$; revised February $1^{\text {st }}, 2014$; accepted February $19^{\text {th }}, 2014$
}

Copyright (C) 2014 Nils-Axel Mörner. This is an open access article distributed under the Creative Commons Attribution License, which permits unrestricted use, distribution, and reproduction in any medium, provided the original work is properly cited. In accordance of the Creative Commons Attribution License all Copyrights @ 2014 are reserved for SCIRP and the owner of the intellectual property Nils-Axel Mörner. All Copyright (C) 2014 are guarded by law and by SCIRP as a guardian.

\section{ABSTRACT}

Nuclear power was designed to produce electric power. Each part of the chain from uranium mining to handling of the waste is linked to serious contamination risks, however. Uranium mining is generally linked to local to regional contamination. The fuel production also produces depleted uranium at a ratio of 1:7. The reactors are operating under danger of accidents. Numerous minor accidents and endless temporary shut-downs are occasionally mixed with disastrous accidents. The Chernobyl (1986) and Fukushima (2011) accidents are notorious. The radioactive contamination from those accidents is still incomprehensible and will keep serious destructions of the environment for centuries to come. The handling of the high-level nuclear waste remains unsolved. Methods proposed in Sweden, Finland and France seem likely to lead to disastrous radioactive contaminations in the future. The only way out of this dilemma seems to be a disposal where the waste, though effectively sealed-off in the bedrock, remains accessible and controllable. At present, the "cost \& benefit" balance seems strongly tilted over to the "far too costly side", however.

\section{KEYWORDS}

\section{Nuclear Power; Uranium Mining; Depleted Uranium; Nuclear Accidents; Waste Handling; The DRD Method}

\section{Introduction}

In human societies, we use to try to balance "cost \& benefit". In the case of nuclear power, it is easy to evaluate the benefit in the form of energy output. The cost, however, is much more problematic. The actual production costs can be fairly well handled. The indirect costs, especially the risks of radioactive contamination of the environment, are far more complicated to handle. Usually, we end up in a strange "pro and con” debate.

In this paper, I will try to assess the risks of radioactive contamination at the main stages of uranium mining and fuel production, the operation and accidents of nuclear power plants, and the handling of the high-level nuclear waste [1].

As a geologist, it is natural to investigate the observational facts as they are revealed and documented in nature itself, and it feels pertinent to quote a sentence by the 2011 Nobel Prize winner in Literature, Tomas Tranströmer; "The truth lies on the ground, but no one dares to grasp it”.

\section{Uranium Mining and Fuel Production}

The process of mining, usually quarrying, of uranium ore deposits is linked to serious health and environmental problems. There are many reports on serious radioactive contamination (e.g. [2,3]).

In order to obtain 1 ton of reactor fuel, about 2600 tons of uranium ore have to be quarried, leaving huge sores in nature and radioactively contaminated soils and waters in the vicinities (e.g. in Kazakhstan, Canada, Australia, Nigeria, Namibia, Russia, USA). In addition to this, each ton of radioactive fuel will also lead to the production of 7 tons of depleted uranium, a highly toxic material, which is used in warheads and leads to serious contaminations of former war areas. This has emerged as a new major problem in the chain of nuclear power production, as illustrated in Figure 1 [1].

\section{Nuclear Power Plant Accidents}

Nuclear power plants (NPP) were, of course, meant to 


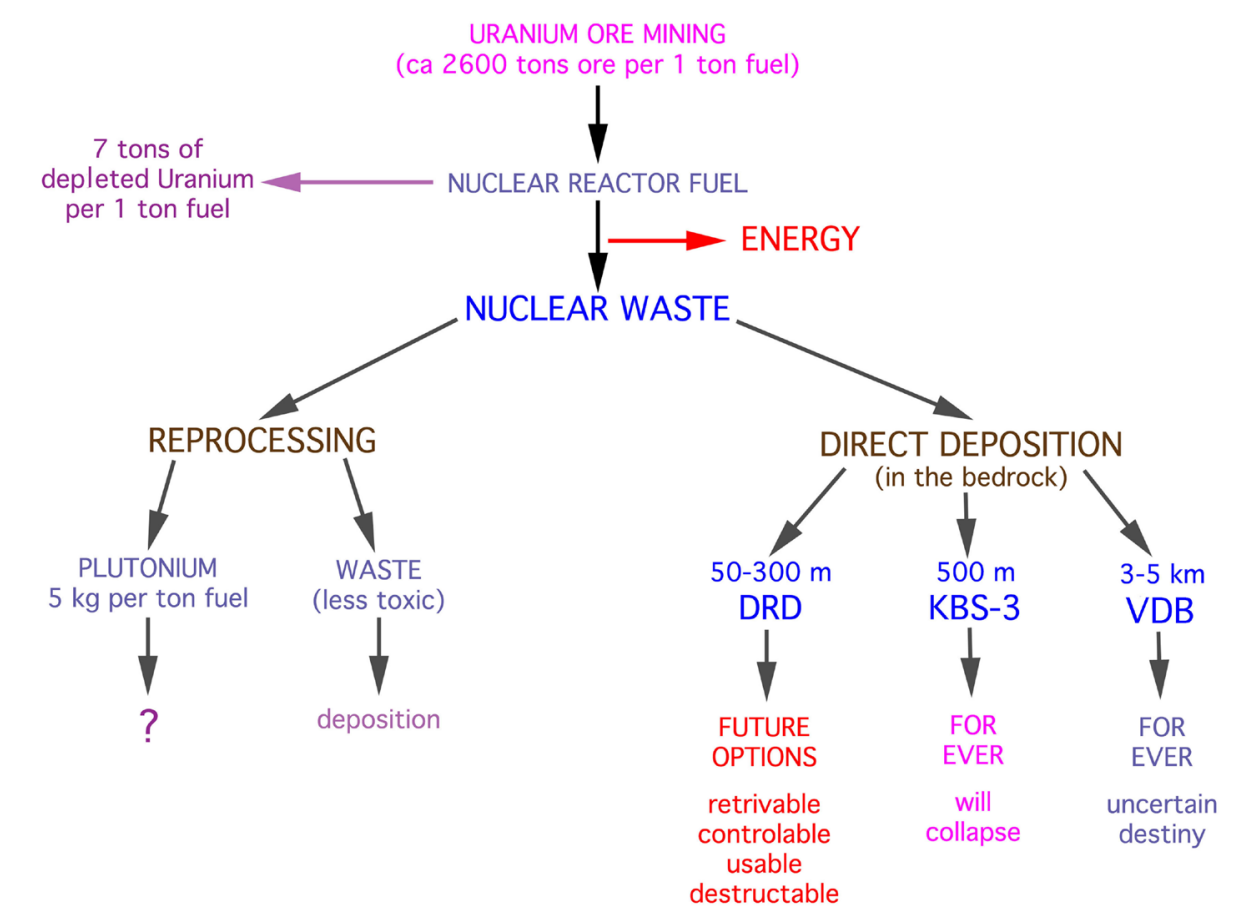

Figure 1. The nuclear fuel chain from uranium mining to optional waste handling (from [1]).

run without accidents. Still, numerous accidents have occurred over the last 60 years (Figure 2). The most serious ones of which have been the Chalk River 1952 accident in Canada, the Kyshtym 1957 accident in Russia, the Harrisburg 1979 accident in USA, the Chernobyl 1986 accident in Ukraine and the Fukushima 2011 accident in Japan. Both Chernobyl and Fukushima reached level 7 on the INES scale.

The Chernobyl accident gave rise to vast radioactive contamination over Europe. In Sweden, there are regions where mushrooms, lake fishes and deer meat still should not be eaten. The death toll has been much debated; from 47 workers that died by acute radiation, to 4000 persons or even 1 million people [4].

The Fukushima-Daiichi accident of March 11, 2011 marks the deepest low-point in the use of nuclear power over the last 60 years. Kurokawa, chairman of the Independent Investigation Commission [5] summarizes the situation as follows: "The earthquake and tsunami of March 11, 2011 were natural disasters of a magnitude that shocked the entire world. Although triggered by these cataclysmic events, the subsequent accident at the Fukushima Daiichi Nuclear Power Plant cannot be regarded as a natural disaster. It was a profoundly manmade disaster - that could and should have been foreseen and prevented. And its effects could have been mitigated by a more effective human response".

It is of fundamental importance that the destruction of the NPPs themselves primarily must be understood in terms of man-made mistakes and shortcomings [5]. The radioactive contamination of surrounding ground, water and air is immense. Vast land areas have so high radioactivity that they should be abandoned, and the contamination will remain for a very long time. The ground water is extensively contaminated. The ocean water has a very strongly increased radioactivity, which seems almost impossible to control. The air pollution is very extensive, and increased radioactivity has been measured almost all over the world. The west coast of North America is strongly affected [6].

The fourth reactor at Fukushima-Daiichi is badly damage raising deep worries for what may happen if a new seismic ground shaking would occur [7].

The dimensions of the Fukushima accident are so extensive and incomprehensible [5] that the "cost \& benefit" balance of nuclear power has come in a totally new situation. In some countries, nuclear power was even abandoned.

\section{Nuclear Waste Handling}

The mere idea of starting nuclear power production before the handling of the waste produced was solved, is, of course, incorrect from an ethical as well as a scientific point of view. It mirrors a strong over-believe in technological innovations, bordering on "hubris".

Each nuclear power plant (and there are 429 of them in the world today) produces waste that must be taken care of in one way or the other. The low-level waste has often been simply dumped in open storages on the ground or in barrels into the sea. The medium-level waste have been 


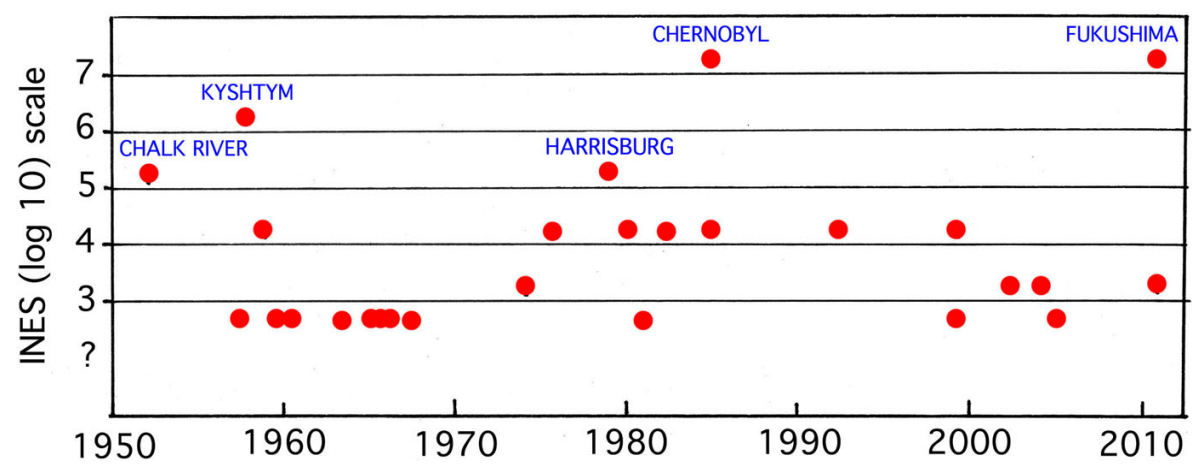

Figure 2. Major nuclear accidents over the past 60 years (1952-2013) with Chernobyl (1986) and Fukushima (2011) as the most disastrous ones (from [1]).

piled up in barrels or containers on fenced-in open ground (e.g. on the Kola Peninsula), piled up in mines (e.g. in Germany) or deposited in underground storages (e.g. Sweden and Finland). The high-level waste is the really problematic material, as its very high toxicity demands that it is kept isolated from the biosphere for "at least 100,000 years". Today, there is, in fact, no satisfactory solution of the problem of how to handle the highlevel waste (e.g. [1,8,9]).

At very many nuclear power plants, the used-up fuel of high-level nuclear waste is simply stockpiled within the power plants themselves. This is one of the reasons why the Fukushima-Daiichi accident became so devastating.

Deposition in salt domes has been discussed (e.g. in Germany), in soft clay beds (in Belgium), in old lithified clay beds (at Bure in France) or in granitic bedrock (USA, Sweden and Finland). None of these options offers adequate long-term safety, however. A form of geological deposition seems reasonable.

The first decision to take is the form of high-level waste to deposit: either a direct deposition of the waste, or a deposition after reprocessing, where the plutonium is separated for the rest of the waste (Figure 1).

The second decision to take is whether the waste should remain accessible and controllable or if it should be sealed-off as a final deposition.

The argument for an accessible deposition is that the waste can be controlled and will remain retrievable for recirculation, transmutation, destruction or simply removal to an improved storage. This is to consider future energy need, technological innovations and the need to keep the waste away from the biosphere at the same time as it can be kept under control and monitoring. The only depositional method that meets these criteria is the DRD-method ([10]; cf. [1,8,9]). The American DOE repository [11] meets some of these criteria, but much less successfully.

The argument for a closed final deposition is simply the hope of finally to get rid of the waste, never ever to be reached again. This was the basic goal of the so-called KBS-3 method favored in Sweden and Finland. It calls for absolute safety for the enormous time-span of "at least 100,000 years" (Sweden) or "up to 1 million years" (Finland), goals that seem illusive, however $[1,12,13]$.

\subsection{The Swedish-Finnish Concept}

The KBS-3 methodology for a final disposal of highlevel nuclear waste was defined in the early 80s [14]. Its basic concept was said to rest on the "very high stability of the Fennoscandian Shield". Today, very little if anything of this assumed "stability" persists. Our geological-geophysical stage of knowledge has passed a major paradigm shift with respect to crustal stability $[1,8$, 12,13,15-17].

In the KBS-3 concept the high-level waste is being encapsulated in cupper canister, which are placed in drillholes at $500 \mathrm{~m}$ depth in the crystalline bedrock, surrounded by bentonite clay and sealed off form connections with the surface $[18,19]$. In Sweden, the repository is claimed to remain intact "for at least 100,000 years" [18] and in Finland "for up to 1 million years" [19].

No one can, of course, make serious safety estimates over such enormous time units $[1,8,13]$. But the case is much worse than so. In both Finland and Sweden, the authorities limit their seismic hazard assessments to seismic records of the last century. This is to carry predictions "in absurdum" [8]. In science, we cannot allow for such analyses. If we want to try to make any meaningful forecasts over such time periods, we must base our estimates on all available data; especially on paleoseismic data [13].

Figure 3 gives the paleoseismic picture $[13,16]$ in direct association to the proposed repositories at Forsmark in Sweden [18] and at Olkiluoto in Finland [19]. It seems both repositories are placed in a high-seismic area in association with the waxing and vanishing of past and future ice caps over the region.

The estimated energy release based on seismological data and on paleoseismic data differs by a factor of 1000 


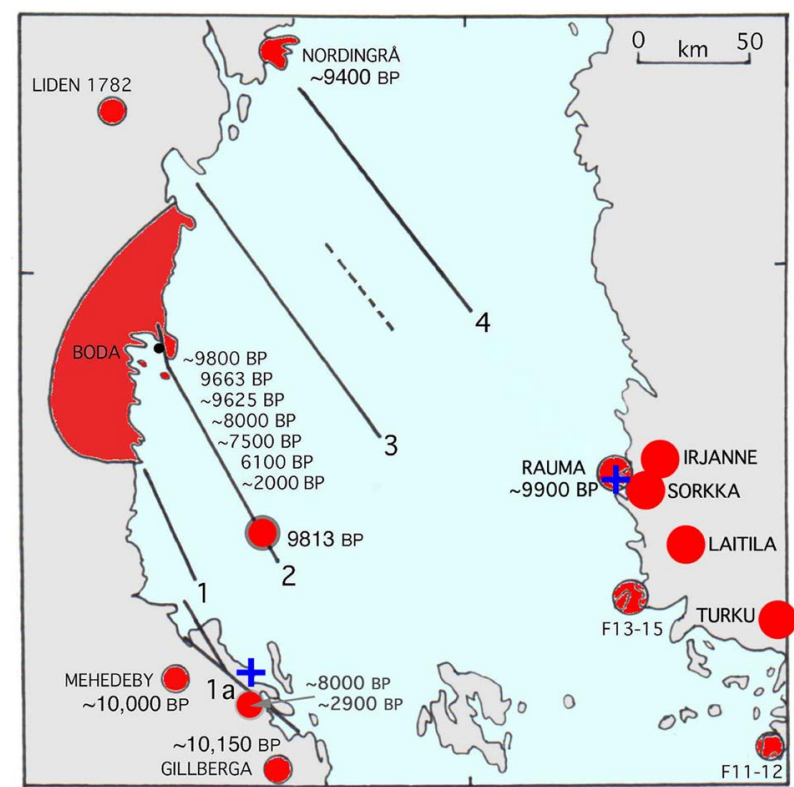

Figure 3. The Bothnian Bay between Sweden (left) and Finland (right) was a high-seismic area during the deglacial phase with maximum rate of uplift ten times higher than the maximum rates of sea-floor spreading today $[8,12,13$, 15-17] and will continue to be so even in the future [13], invalidating the long-term safety of the repositories proposed at Forsmark in Sweden and Olkiluoto in Finland (blue crosses). Red marks with dates denote sites of documented, dated and described paleoseismic events [16].

billions $[1,13,16]$. Whilst SKB [18] predicts 0.1 magnitude 6 events in 100,000 years at the Swedish site, the paleoseismic database [13] would suggest $\sim 40 \mathrm{M}>8$, $\sim 50 \mathrm{M} 7-8, \sim 190 \mathrm{M} 6-7$ and alt least $70 \mathrm{M}>6$ events within next 100,000 years.

The conclusion seems obvious [13]: "there will be far too many and far too strong events in the future to allow for statements that a closed repository of KBS-3 type will stay intact over the required time period of at least 100,000 years. The opposite seems rather to be the case: no safe deposition".

A future failure of a KBS-3 repository would imply immense radioactive contaminations of the regional groundwater and the whole of the Baltic. The consequences for human health seem incomprehensible.

\subsection{Alternative Options}

With the failure of the KBS-3 method [1,13], we seem to have reached a "dead-end situation" for a safe handling of the high-level nuclear waste. This calls for an alternative handling. For the Swedish-Finnish situation, there are only two options; a final deposition in very deep boreholes (VDB) at a depth of $3-5 \mathrm{~km}$ [20] or an accessible deposition in a DRD-repository [10] as illustrated in Figure 1.

The VDB-deposition [20] is proposed for the basic reason of "getting rid of the waste forever" and placing it out of reach of terrorists.

The DRD-method [1,8-10], on the other hand, would imply that the waste is deposited safely in the bedrock, but still accessible and controllable (Figure 4). The repository itself (in caverns or tunnels) is surrounded by artificial fracture zone so that the depositional environment becomes a dry rock deposit (DRD). The fracture zones will also act as excellent barriers for seismic destruction. A DRD-repository can be designed in several different ways [10], viz. as an intermediate storage, as a long-term storage (up to the next Ice Age) or even as a "final" storage. The main philosophy behind this type of repository is that we must keep the freedom of action, the possibility of control and monitoring of the waste, the option of retrievability for recycling, destruction or re-location. The repository does not require any safeguard, but allows for auto-monitoring and control that minimizes the risks of radioactive contamination.

\section{Energy Need}

The need of a constant supply of an adequate amount of energy is a base for human progress and civilization. For the last decades, we have understood that some of our present energy resources are starting to run-out. In this situation, it is often claimed that nuclear power takes a necessary part, sometimes even without considering the cost $\&$ benefit balance.

Our search for new energy resources and new energy processes is vital. Thanks to the new option of shale gas, we have extended the desperate need for another century, or so. At the transitional stage into new energy systems, the situation is likely to become desperate and all means of obtaining energy may have to be employed. In this situation (Figure 5), one may even say that it is a moral demand to keep the nuclear waste accessible for future energy needs [21], which is another reason for proposing a DRD-methodology [10].

\section{Discussion}

Nothing is as harmful and long lasting as radioactive contamination. The mining operation is linked to contamination of soil, water and air. The production of 1 ton of nuclear fuel also gives rise to 7 tons of depleted uranium. Depleted uranium is a very bad environmental pollutant. It ought to be safely stored, but is instead spread via the use in warheads (and probably even other processes, because we see no efforts of storage of depleted uranium). Accidents of nuclear power plants in operation — especially Chernobyl and Fukushima—generate terrible effects of radioactive contamination spread by air and water over enormous distances. Just this, should make the "cost \& benefit" balance to tilt over to the "far 


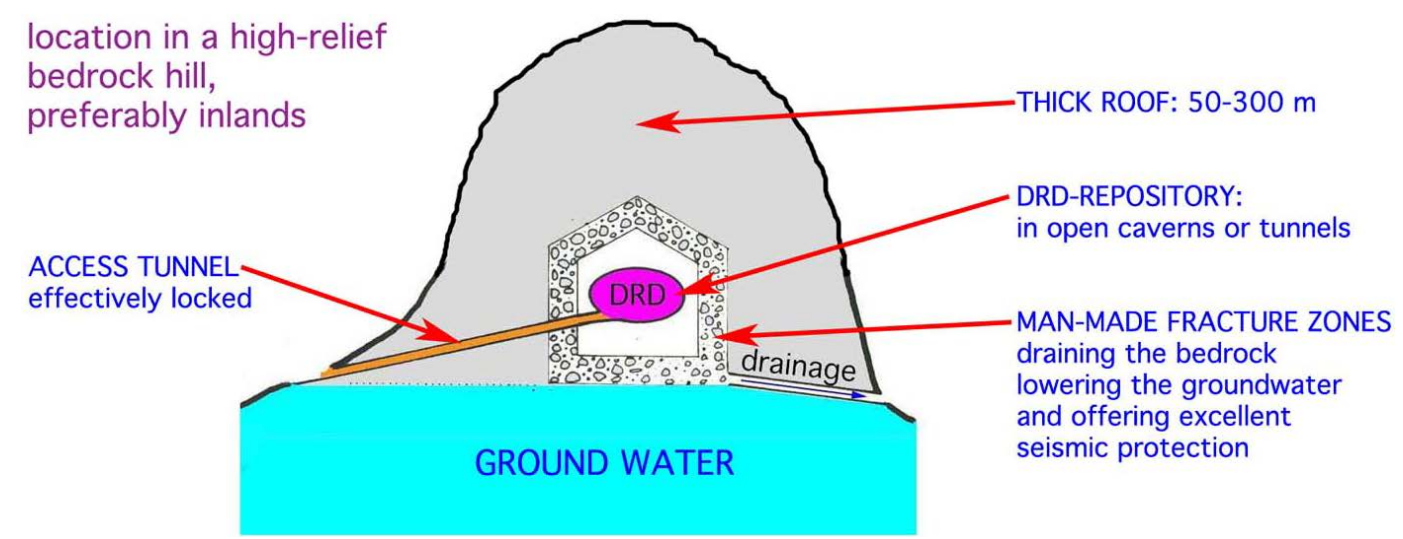

Figure 4. Principle sketch of a DRD-repository [10]. The waste is deposited in caverns or tunnels surrounded by artificial (man-made) fracture zones, which drain the rock masses inside and acts as a very efficient seismic protection. The waste, though well sealed-off, will remain accessible and controllable; i.e. the freedom of action is kept.

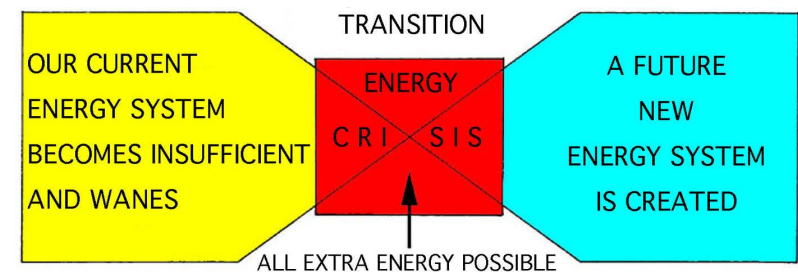

Figure 5. When our present energy system becomes insufficient and before we have created a new energy system, we are likely to pass a very problematic transitional period of a deep energy crisis. Then we will need extra supply from all available energy sources. Our high-level nuclear waste (were $96 \%$ of the energy remains unused) may then become a direct salvation-provided it remains accessible like in a DRD-repository (modified from [21]).

too costly" side. The unsolved issue of how to handle the waste poses immense problems. Some of the methods proposed (e.g. in Sweden, Finland and France) seem nearly bound to end up in disastrous future contaminations of bedrock environments, groundwater and ocean systems.

This means that nuclear power has been operating, is presently operating and will for an unknown period into the future be operating under unsafe conditions and with far too high risks for radioactive contamination of global environments (Figure 6). If, in the future, technological innovations will ever generate new types of reactors that may be classified as "safe" and recycle their own waste, the situation may perhaps change. If this would really be achieved, our old high-level waste may be re-used and destroyed: the more reason, today, for keeping it accessible in a DRD-repository (Figure 6).

\section{Conclusion}

In conclusion, however, today's operation of nuclear power includes far too high risks of disastrous contamination: 1) at the fuel production, 2) at the reactor opera-

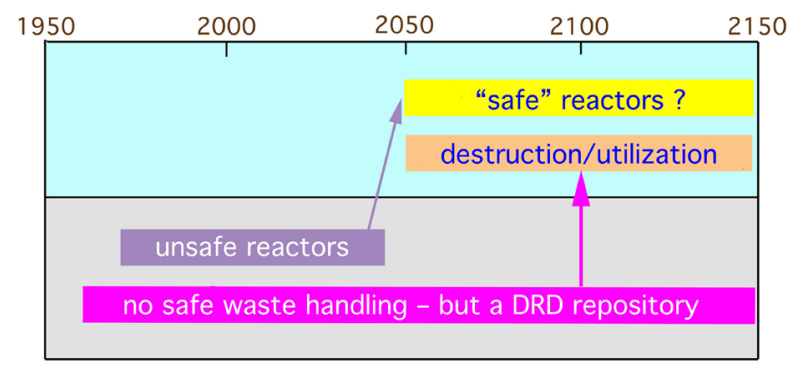

Figure 6. Nuclear power was not a safe technology for the late $2^{\text {th }}$ century; nor is it today. In the future the situation may perhaps change so that the high-level waste can be used and destroyed. This requires a present deposition that keeps the waste accessible, however [1].

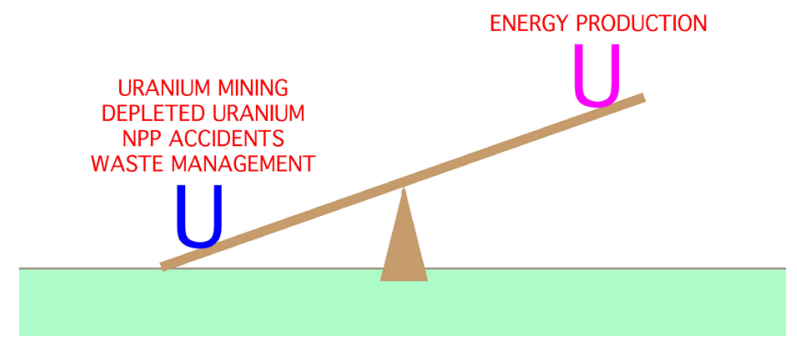

Figure 7. The radioactive contamination risks in association with uranium mining, production of depleted uranium, severe power plant accidents and high-level waste handling poses such great problems that the "cost \& benefit" balance of nuclear power seems strongly tilted over to the left side of far too great negative effects.

tion and 3) at the waste management. The "cost \& benefit" balanced seems strongly tilted over to the "far too costly side” (Figure 7).

\section{REFERENCES}

[1] N.-A. Mörner, "Collapse, Kollaps, Romahdus (in: English, Swedish \& Finnish),” P\&G-Print, Stockholm, 2013, p. 72. http://www.nonuclear.se/morner2013collapse-kollaps-ro 
mahdus

[2] "Addressing Uranium Contamination on the Navajo Nation," 2013.

http://www.epa.gov/region9/superfund/navajo-nation/

[3] “Church Rock Uranium Mill Spill,” 2013. http://en.wikipedia.org/wiki/Church_Rock_uranium_mill spill

[4] “Chernobyl Death Toll Grossly Underestimated," 2006. http://www.greenpeace.org/international/en/news/features /chernobyl-deaths-180406/

[5] K. Kurokawa, “The National Diet of Japan,” The Official Report of the Fukushima Nuclear Accident Independent Investigation Commission, 2012, p. 86.

[6] "28 Signs That the West Coast Is Being Absolutely Fried with Nuclear Radiation from Fukushima,” 2013.

http://dcclothesline.com/2013/10/22/28-signs-west-coastabsolutely-fried-nuclear-radiation-fukushima/

[7] "David Suzuki's Fukushima Warning Is Dire and Scary," 2013.

http://www.huffingtonpost.ca/2013/11/04/david-suzuki-fu kushima-warning_n_4213061.html?utm_hp_ref=tw

[8] N.-A. Mörner, "In Absurdum: Long-Term Predictions and Nuclear Waste Handling," Engineering Geology, Vol. 61, No. 2-3, 2001, pp. 74-82.

http://dx.doi.org/10.1016/S0013-7952(01)00037-0

[9] B. Cronhjort and N.-A. Mörner, "A Question of Dry vs Wet. The Case for Dry Rock Disposal of Nuclear Waste,” Radwaste Solutions, 2004, pp. 44-47.

[10] N.-A. Mörner, “The DRD Method-DRD Metoden: A Short Presentation-En Kort Presentation (in English \& Swedish),” P\&G-Print, Stockholm, 2013, p. 28. http://www.nonuclear.se/drd_method2013morner

[11] US National Regulatory Commission, “DOE's License Application for High-Level Waste Geological Repository at Yucca Mountain,” 2008. http://www.nrc.gov/waste/hlw-disposal/yucca-lic-app.html

[12] N.-A. Mörner, "Paleoseismology: The Application of Mul- tiple Parameters in Four Case Studies in Sweden," Quaternary International, Vol. 242, No. 1, 2011, pp. 65-75. http://dx.doi.org/10.1016/j.quaint.2011.03.054

[13] N.-A. Mörner, "Patterns in Seismology and Palaeoseismology, and Their Application in Long-Term Hazard Assessments-The Swedish Case in View of Nuclear Waste Management," Pattern Recognition in Physics, Vol. 1, No. 1, 2013, pp. 75-89. http://dx.doi.org/10.5194/prp-1-75-2013

[14] KBS (Svensk Kärnbränsle Säkerhet), “Kärnbränslecykelns Slutsteg, Använt Kärnbränske-KBS-3,” Vol. II, Geologi, 1983, p. 90.

[15] N.-A. Mörner, "Intense Earthquakes and Seismotectonics as a Function of Glacial Isostasy," Tectonophysics, Vol. 188, No. 3-4, 1991, pp. 407-410. http://dx.doi.org/10.1016/0040-1951(91)90471-4

[16] N.-A. Mörner, "Paleoseismicity of Sweden—A Novel Paradigm," A Contribution to INQUA from Its Sub-Commission on Paleoseismology at the 16th International INQUA Congress in Reno, P\&G Print, Stockholm, 2003, p. 320/

[17] N.-A. Mörner, "Drainage Varves, Seismites and Tsunamites in the Swedish Varve Chronology," GFF, Vol. 135, No. 3-4, 2013, pp. 308-315. http://dx.doi.org/10.1080/11035897.2013.764546

[18] SKB (Svensk Kärnbränslesäkerhet), "Redovisning av Säkerhet efter Förslutning av Slutförvaret för Använt Kärnbränsle,” Huvudrapport Från Project SR-Site, Del I-III, 2011.

[19] Posiva, "Safety Case for the Disposal of Spent Nuclear Fuel at Olkiluoto-Formulation of Radionuclide Release Scenarios,” Posiva 2012-08, Posiva Oy, 2012.

[20] K.-I. Åhäll, "Final Deposition of High-Level Nuclear Waste in Very Deep Boreholes-An Evaluation Based on Recent Research of Bedrock Conditions at Great Depths," MKG-Print, 2006.

[21] N.-A. Mörner, “Detta Eviga Avfall,” PQR-Kultur, 2009, p. 100. 